\title{
A reclassification and description of the Waterberg Mountain vegetation of the Marakele National Park, Limpopo province, South Africa
}

\begin{tabular}{|c|c|}
\hline \multicolumn{2}{|c|}{$\begin{array}{l}\text { Authors: } \\
\text { Petrus J. van Staden }{ }^{1} \\
\text { George J. Bredenkamp } \\
\text { Hugo Bezuidenhout }{ }^{2,3} \\
\text { Leslie R. Brown }\end{array}$} \\
\hline \multicolumn{2}{|c|}{$\begin{array}{l}\text { Affiliations: } \\
{ }^{1} \text { Department of Botany, } \\
\text { University of Pretoria, } \\
\text { Pretoria, South Africa }\end{array}$} \\
\hline \multicolumn{2}{|c|}{$\begin{array}{l}{ }^{2} \text { Scientific Services, SANParks, } \\
\text { Kimberley, South Africa }\end{array}$} \\
\hline \multicolumn{2}{|c|}{$\begin{array}{l}{ }^{3} \text { Applied Behavioural } \\
\text { Ecology and Ecosystem } \\
\text { Research Unit, Faculty of } \\
\text { Environmental Sciences, } \\
\text { University of South Africa, } \\
\text { Florida, South Africa }\end{array}$} \\
\hline \multicolumn{2}{|c|}{$\begin{array}{l}\text { Corresponding author: } \\
\text { Leslie Brown, } \\
\text { Irbrown@unisa.ac.za }\end{array}$} \\
\hline \multicolumn{2}{|c|}{$\begin{array}{l}\text { Received: } 25 \text { June } 2021 \\
\text { Accepted: } 08 \text { Oct. } 2021 \\
\text { Published: } 10 \text { Dec. } 2021\end{array}$} \\
\hline \multicolumn{2}{|c|}{$\begin{array}{l}\text { How to cite this article: } \\
\text { Van Staden, P.J., Bredenkamp, } \\
\text { G.J., Bezuidenhout, H. \& } \\
\text { Brown, L.R., 2021, 'A } \\
\text { reclassification and } \\
\text { description of the Waterberg } \\
\text { Mountain vegetation of the } \\
\text { Marakele National Park, } \\
\text { Limpopo province, South } \\
\text { Africa', Koedoe 63(1), a1689. } \\
\text { https://doi.org/10.4102/ } \\
\text { koedoe.v63i1.1689 }\end{array}$} \\
\hline \multicolumn{2}{|c|}{$\begin{array}{l}\text { Copyright: } \\
\text { (c) 2021. The Authors. } \\
\text { Licensee: AOSIS. This work } \\
\text { is licensed under the } \\
\text { Creative Commons } \\
\text { Attribution License. }\end{array}$} \\
\hline \multicolumn{2}{|l|}{ Read online: } \\
\hline 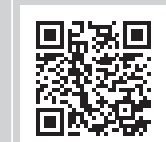 & $\begin{array}{l}\text { Scan this QR } \\
\text { code with your } \\
\text { smart phone or } \\
\text { mobile device } \\
\text { to read online. }\end{array}$ \\
\hline
\end{tabular}

The description and classification of vegetation are important for conservation and resource management. The aim of this study was to identify, reclassify and describe the plant communities present in the Waterberg Mountain vegetation of the Marakele National Park in the Limpopo province, South Africa. A phytosociological classification, mapping and description of sections of the Waterberg Mountain vegetation in the park were done in 1995. Since 1995, various farms adjacent to the park have been bought and incorporated into it. Little is known about the vegetation and habitat status of these newly acquired areas, which led to this study. The floristic data were analysed according to the Braun-Blanquet procedure using the Braun Blanquet Personal Computer (BBPC) suite as well as the JUICE software package, whilst the diversity of the plant communities was determined using the Shannon-Wiener and Gini-Simpson indices. A total of 12 plant communities were identified and are described according to their diagnostic, constant and dominant plant species as determined from the synoptic table analysis as well as their characteristic species as derived from the phytosociological table. Based on the topography and plant species composition, the vegetation can be grouped into five major groups, namely the: (1) lower midslope and plateau shrub- and woodlands, (2) high altitude midslope woodland, (3) high-lying plateau and midslope grass-, shrub- and woodlands, (4) ravine, footslope and drainage line forests and woodland, and (5) higher-lying plateau wetlands and forblands. The high altitude midslope grassland and shrubland and the lower midslope and plateau areas have the highest diversity. The high-lying vegetation has affinity with Bankenveld and Drakensberg vegetation, whilst the relatively low-lying plateaus and midslope vegetation are typical of the bushveld areas.

Conservation implications: This reclassification, mapping and description of the Waterberg Mountain vegetation have been incorporated into the Management Plan for the park. It will enable managers to make scientifically based decisions on the management of the different ecosystems to ensure biodiversity conservation. This vegetation study also provides baseline information that allows for vegetation assessments to determine veld condition, carrying capacity and stocking density for the park.

Keywords: Marakele National Park; JUICE; phytosociology; diversity; vegetation structure; nature conservation.

\section{Introduction}

Marakele National Park including Marakele Park (Pty) Ltd (referred to as Marakele in the text) is managed under the jurisdiction of South African National Parks. The park was established in 1988 and was proclaimed as a national park in February 1994 (Van Staden 2002). Since 1995, various farms adjacent to the original Marakele have been bought and incorporated into the park. These new areas have not only resulted in the park more than doubling its size from its previous $290.51 \mathrm{~km}^{2}$ (29051 ha) to approximately $700.00 \mathrm{~km}^{2}$ (70000 ha) but included new ecosystems and made the re-introduction of various large mammals such as elephant, buffalo, black- and white rhinoceros and predators such as lion possible (Van Staden 2007).

The necessity for a vegetation classification, description and mapping of conservation areas was stated by Bezuidenhout (2009). In order to manage and conserve our natural heritage for current and future generations, a profound knowledge of the different ecosystems is a prerequisite. To achieve this, an inventory of the biotic and abiotic components of the different ecosystems

Note: Additional supporting information may be found in the online version of this article as Online Appendix 1. 
needs to be compiled to assist with informed management decision making (Brown et al. 2013; Van Staden 2002).

Various studies on sections of the mountain vegetation of the original Marakele National Park were undertaken in the past by Van Staden (2002) and Van Staden and Bredenkamp (2005). These studies described the vegetation of selected sections of the mountainous areas of the original park only. This study was undertaken to provide a detailed classification and ecological interpretation of the mountain vegetation of Marakele (Marakele National Park including Marakele Park [Pty] Ltd).

\section{Study area}

\section{Location and size}

Marakele is situated approximately $13 \mathrm{~km}$ east of the town of Thabazimbi, in the Limpopo province, South Africa (see Figure 1). It extends from latitude $24.54081^{\circ}$ to $24.49407^{\circ} \mathrm{S}$ and longitude $027.44802^{\circ}$ to $027.76378^{\circ} \mathrm{E}$ (Van Staden 2015).

\section{Geology}

Marakele is underlain by various geological formations. The geology of the mountainous area of Marakele consists of rocks belonging to the Kransberg subgroup, which consists of yellowish, coarse-grained sandstone, locally gritty, with ferruginous laminae on cross-bedding planes of the Sandriviersberg Stage, Kransberg Series of the Sandriviersberg Sandstone Formation with a thickness of approximately $1250 \mathrm{~m}$, and covers the largest part of the study area in the Waterberg Mountain in Marakele (Van Staden 2015). The Waterberg rocks were faulted and intruded by diabase sills and dykes of the Post Waterberg to the southern and northern areas of Marakele (Van Staden 2015).

\section{Physiography, soil, land types and vegetation}

The mountainous landscape includes upper and low-lying valleys and drainage lines, together with steep to moderately steep mountain slopes and relatively flat to undulating plateaus. Altitude ranges from $1200 \mathrm{~m}$ to $2100 \mathrm{~m}$ above the mean sea level. The following topographical terrain units are distinguished in Marakele: plateau (1), scarp (2), midslopes (3), footslopes (4), wetlands and drainage lines (5) (Land Type Survey Staff 1988). The Matlabas-, Sterkstroom-, Sondags- and Mamba rivers form the core of the drainage system of the area.

The study area comprises three land types, namely Ad, $\mathrm{Fa}$ and $\mathrm{Ib}$ (Land Type Survey Staff 1988). The soil varies from deep $(>0.8 \mathrm{~m}$ ) red-brown and yellow-brown sands

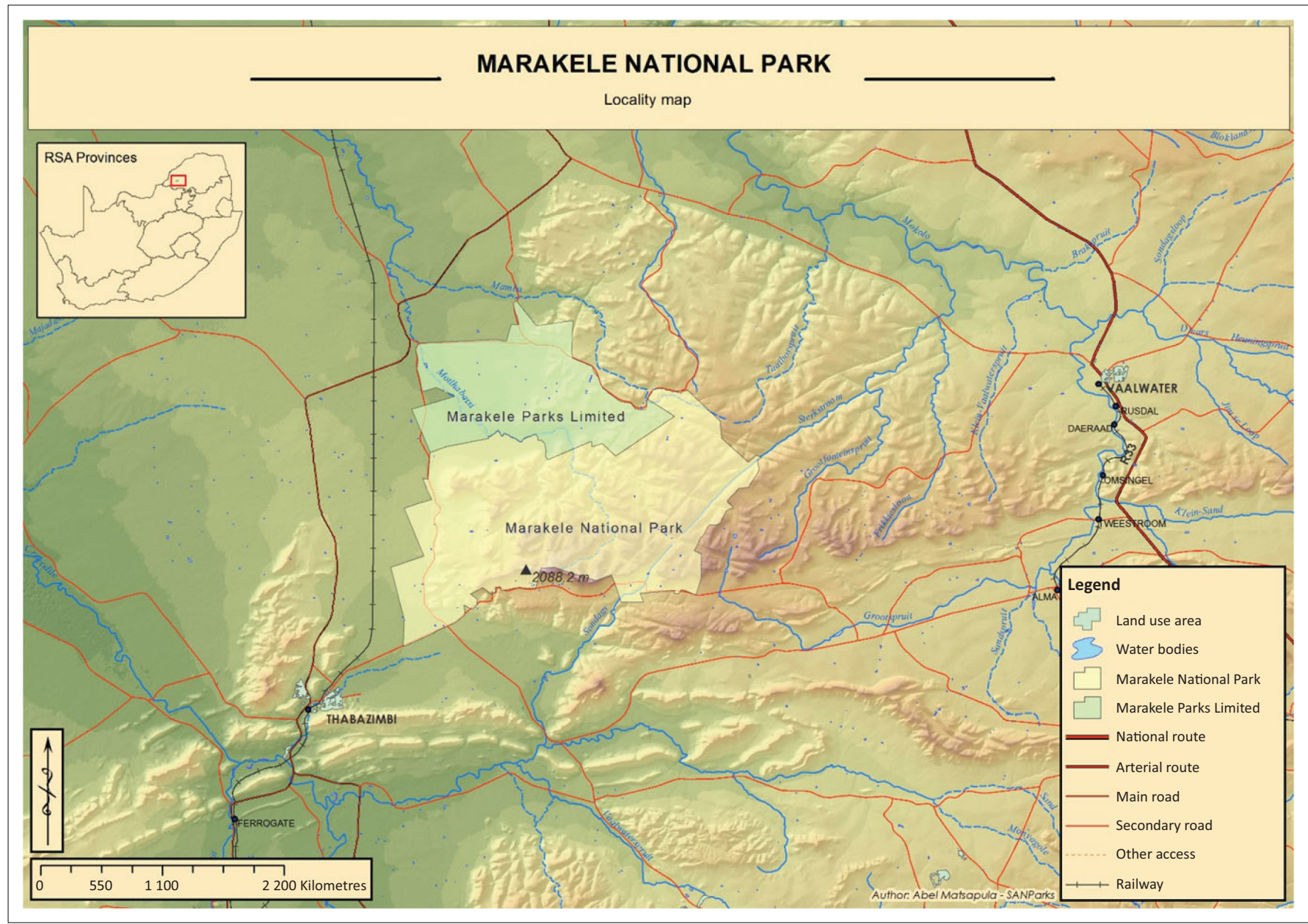

Source: Mapped by Mr A. Matsapula, SANParks.

FIGURE 1: The location of the Marakele National Park. 
(Avalon, Champagne, Clovelly, Hutton, Katspruit, Oakleaf and Westleigh soil forms) to shallow $(<0.3 \mathrm{~m})$ and stony (Mispah and Glenrosa soil forms) (Soil Classification Working Group 1991; Van Staden 2015).

Mucina and Rutherford (2006) classified the vegetation of Marakele as the Western Sandy Bushveld (SVcb16) and the Waterberg Mountain Bushveld (SVcb17) vegetation types in the Savanna Biome, the Waterberg-Magaliesberg Summit Sourveld (GM29) vegetation type in the Grassland Biome and the Marakele Afromontane Forest (FOz2) in the Northern Afromontane Forest vegetation type in the Afrotemperate, Subtropical and Azonal Forests Biome of South Africa.

\section{Climate}

The rainfall, mainly during the spring and summer (September-March), can range from as high as 1196.9 to lower than $400 \mathrm{~mm}$ per year. The mean annual rainfall for Marakele based on data collected in Marakele is ca. $704.5 \mathrm{~mm}$ per annum (Van Staden 2015). The park recorded winter temperatures (coldest months June-July) as low as $-3.7{ }^{\circ} \mathrm{C}$, whilst the summer temperatures (warmest months December to February) can reach a maximum temperature of $40.0^{\circ} \mathrm{C}$. Mean frost days per annum is 16 days with the earliest occurrence 14 May and the latest occurrence 23 July (Van Staden 2015).

\section{Materials and methods}

Using 1:50 000 stereo aerial photographs (Task 874 of 1984), the study area was stratified into relatively uniform physiographic-physiognomic units. After a reconnaissance of the area, sample plots were placed in a stratified random manner (Brown et al. 2013) within the different homogeneous units identified. The number of sample plots for each delineated physiographic-physiognomic unit was determined according to the size of each delineated unit. The larger the area, the higher the number of sampling plots allocated to the unit. A total of 136 sample plots were located within these units to ensure that all variations in the vegetation were considered and sampled. Global positioning system (GPS) locations of all sample plots were noted. Plot sizes were fixed at approximately $200 \mathrm{~m}^{2}$ according to Van Staden (2002).

The floristic data were analysed according to the Braun-Blanquet procedure. The Braun Blanquet Personal Computer (BBPC) suite (Bezuidenhout, Biggs \& Bredenkamp 1996) was used to capture the data from where it was imported into the JUICE software package (Roleček et al. 2009; Tichy \& Holt 2006). The numerical classification method TWINSPAN (Hill 1979) was used to provide a hierarchical classification of the mountainous vegetation of the study area. The classification results were used to compile a phytosociological table in which the species were manually rearranged into species groups as described by Brown et al. (2013), but no relevés or clusters were modified. A synoptic table was compiled for the different plant communities using the JUICE 7.1.21 software package (Tichy \& Holt 2006). A combined synoptic table analysis of columns was performed with the lower threshold values set as follows: Fidelity - 70; Frequency - 80 and cover -30 . The different plant communities are described according to their diagnostic, constant and dominant plant species (Tichy \& Holt 2006) as determined from the synoptic table analysis as well as their characteristic species as derived from the phytosociological table. A vegetation map was compiled by overlaying the GPS locations of the sample plots and their classification on georeferenced Google Earth images.

The structural classification for this study was based on the broad scale structural classification of Edwards (1983). The tree stratum includes all single- and multi-stemmed woody, self-supporting plants $3 \mathrm{~m}$ and taller, and the shrub stratum is classified as single- or multi-stemmed woody, self-supporting plants $<3 \mathrm{~m}$ high (adapted from Edwards 1983).

Species richness was determined for each plant community by determining the number of species present in each. The Shannon-Wiener index of diversity $(H)$ (Shannon \& Weaver 1949) and the Rich-Gini-Simpson index of diversity (RGS) (Guiasu \& Guiasu 2010) were calculated for each of the major plant communities.

Shannonon-Wiener Index $(H)=-\sum_{i=1}^{s} p_{i} \ln p_{i}$

[Eqn 1]

Rich - Gini - Simpson Index $(R G S)=n-\sum_{i} p_{i}\left(1-p_{i}\right)$

where $P i=$ (number of individuals of one species) $/$ (total number of all individuals)

The cover-abundance data collected using the BraunBlanquet surveys were transformed to a numerical scale $(r=0.5 ;+=1 ; 1=2 ; 2 \mathrm{a}=8.5 ; 2 \mathrm{~b}=17.5 ; 3=35 ; 4=70 ; 5=140)$ to calculate species diversity as described by Van der Maarel (2007). The diversity results from the indices were converted to true diversities (effective numbers) as described by Jost (2006) to give them common behaviours and properties that allow for appropriate comparisons between plant communities.

Effective number $=\exp \left(-\sum_{i=1}^{s} P i \ln P i\right)$

[Eqn 3]

\section{Ethical considerations}

This article followed all ethical standards for research without direct contact with human or animal subjects.

\section{Results \\ Classification}

The analysis of the Waterberg Mountain vegetation in Marakele resulted in the identification of 12 plant communities, 16 sub-communities and two variants that are indicated in the phytosociological table and vegetation map (Online 
Appendix 1 \& Figure 2) and are listed below (the subcommunities and the variants were omitted from the vegetation map as their distribution is too limited to be visible at the scale on the vegetation map).

1. Themeda triandra-Senegalia caffra woodland

1.1 Themeda triandra-Senegalia caffra-Eragrostis curoula sub-community

1.2 Themeda triandra-Senegalia caffra-Eragrostis chloromelas sub-community

\subsubsection{Themeda triandra variant \\ 1.2.2 Triumfetta sonderi variant}

2. Tristachya leucothrix-Protea welwitschii shrubland

3. Monocymbium ceresiiforme-Andropogon schirensis grassland

3.1 Monocymbium ceresiiforme-Andropogon schirensisProtea gaguedi sub-community

3.2 Monocymbium ceresiiforme-Andropogon schirensisHelichrysum kraussii sub-community

4. Indigofera mollicoma-Encephalartos eugene-maraisii shrubland

5. Tephrosia elongata-Protea caffra woodland

5.1 Tephrosia elongata-Protea caffra-Gerbera viridifolia sub-community

5.2 Tephrosia elongata-Protea caffra-Brachiaria serrata subcommunity
6. Combretum molle-Setaria lindenbergiana woodland

6.1 Combretum molle-Setaria lindenbergiana-Brachylaena rotundata sub-community

6.2 Combretum molle-Setaria lindenbergiana-Diplorhynchus condylocarpon sub-community

7. Perotis patens-Burkea africana woodland

7.1 Perotis patens-Burkea africana-Fadogia homblei subcommunity

7.2 Perotis patens-Burkea africana-Gardenia volkensii subcommunity

8. Kirkia wilmsii-Buxus macowanii forest

9. Diospyros whyteana-Calodendron capensis forest

10. Cyperus albostriatus-Podocarpus latifolius forest

10.1 Cyperus albostriatus-Podocarpus latifolius-Rothmannia capensis sub-community

10.2 Cyperus albostriatus-Podocarpus latifolius-Widdringtonia nodiflora sub-community

11. Syzygium cordatum-Ischaemum fasciculatum woodland

11.1 Syzygium cordatum-Ischaemum fasciculatumSchoenoplectus corymbosus sub-community

11.2 Syzygium cordatum-Ischaemum fasciculatum-Osmunda regalis sub-community

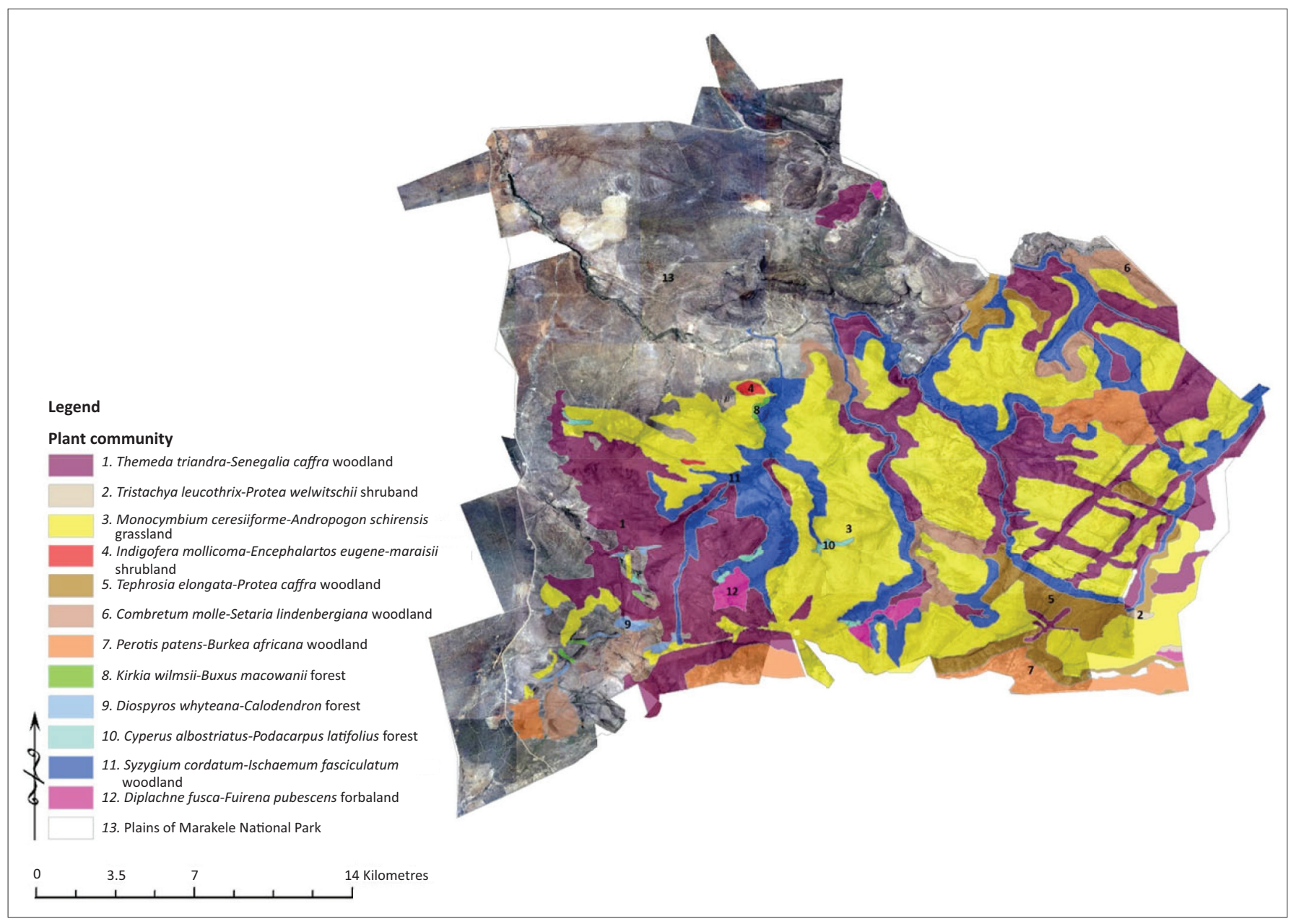

FIGURE 2: Plant communities of the mountainous vegetation of Marakele National Park. 
12. Leptochloa fusca-Fuirena pubescens forbland

12.1 Leptochloa fusca-Fuirena pubescens-Aristida junciformis sub-community

12.2 Leptochloa fusca-Fuirena pubescens-Drosera madagascariensis sub-community

Table 1 provides a summary of the various soil, land type, terrain units and geology associated with each plant community, whilst Table 2 lists the mean height classes (m) and percentage canopy cover for the tree, shrub and herbaceous (grasses and forbs) layers.

\section{Description of the plant communities}

All references to species groups in the descriptions of the various plant communities refer to the phytosociological table (see Online Appendix 1), whilst the diagnostic, constant and dominant species were obtained from the analysis of the synoptic table as described in the methods.

\section{Themeda triandra-Senegalia caffra woodland}

This community is situated on the midslopes and plateaus of Marakele (see Figure 2). Altitude ranges from $1300 \mathrm{~m}$ to $1600 \mathrm{~m}$ above the mean sea level (mamsl). The slopes are gentle to moderate and vary from $4^{\circ}$ to $16^{\circ}$. Rock cover varies between $10 \%$ and $75 \%$ and occurs as loose rocks and boulders.

Species from species group A are characteristic of this woodland. The tree Senegalia caffra (species group A) and the grasses Themeda triandra and Setaria sphacelata (species group V) dominate the woody and herbaceous layers, respectively. This plant community has a total of 129 plant

TABLE 1: Summary of soil parameters relating to each plant community.

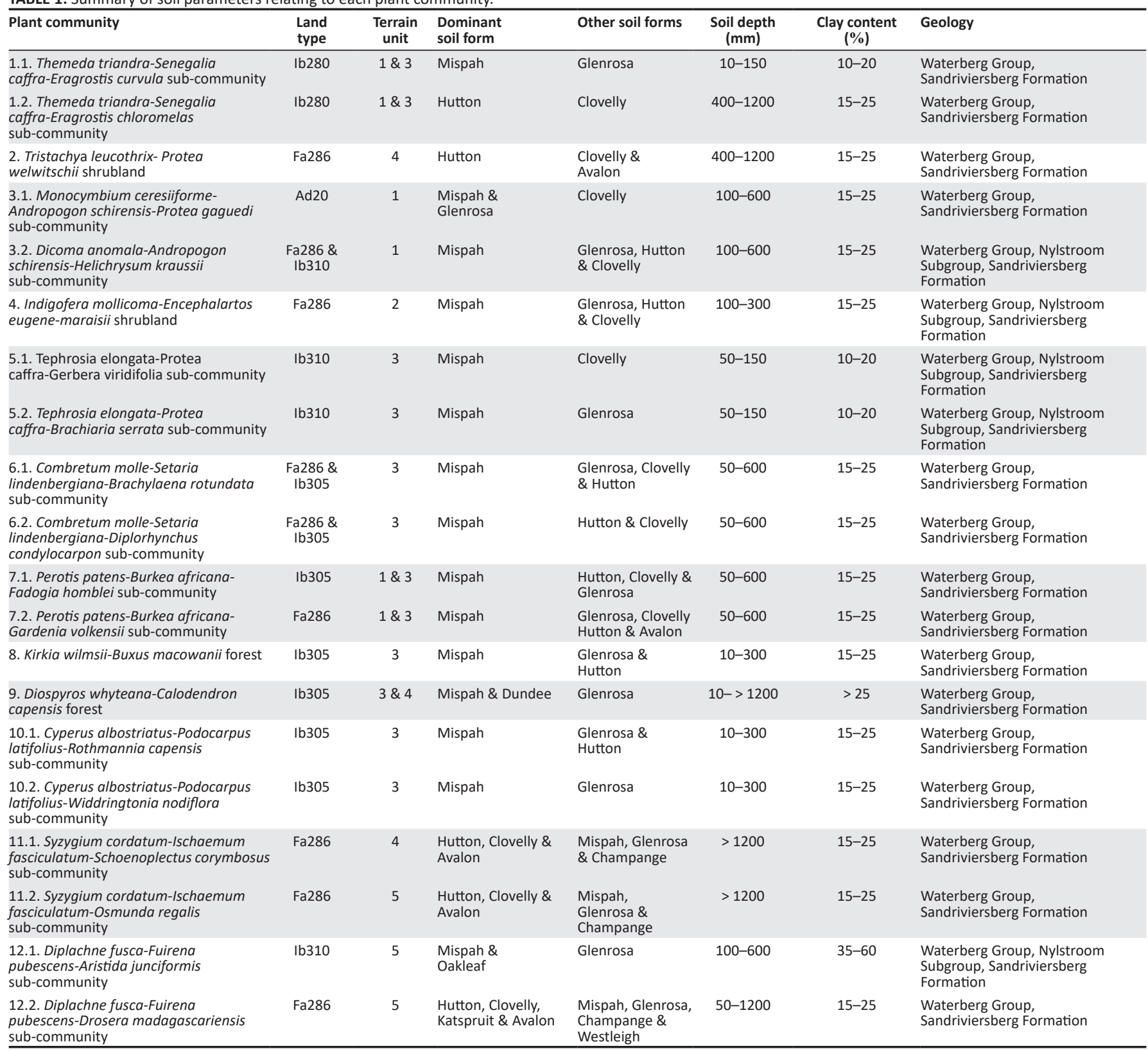


TABLE 2: Summary of the average height classes $(\mathrm{m})$ and - cover abundance $(\%)$ relating to each plant community.

\begin{tabular}{|c|c|c|c|c|c|c|}
\hline \multirow[t]{2}{*}{ Plant community } & \multicolumn{3}{|c|}{ Height class (m) } & \multicolumn{3}{|c|}{ Cover abundance $(\%)$} \\
\hline & Tree & Shrub & Herbaceous & Tree & Shrub & Herbaceous \\
\hline 1.1 Themeda triandra-Senegalia caffra-Eragrostis curvula sub-community & 4 & 1.1 & 0.8 & 80 & 19 & 70 \\
\hline 1.2 Themeda triandra-Senegalia caffra-Eragrostis chloromelas sub-community & 5 & 1.1 & 0.8 & 53 & 15 & 29 \\
\hline 2. Tristachya leucothrix-Protea welwitschii shrubland & - & 0.8 & 1 & - & 10 & 18 \\
\hline 3.1 Monocymbium ceresiiforme-Andropogon schirensis-Protea gaguedi sub-community & - & 0.8 & 1 & - & 3 & 30 \\
\hline 3.2. Monocymbium ceresiiforme-Andropogon schirensis-Helichrysum kraussii sub-community & 3 & 1.3 & 0.8 & 2 & 1.5 & 23 \\
\hline 5.1 Tephrosia elongata-Protea caffra-Gerbera viridifolia sub-community & 3 & 1.5 & 1.6 & 13 & 7 & 36 \\
\hline 5.2 Tephrosia elongata-Protea caffra-Brachiaria serrata sub-community & 3 & 1.8 & 0.8 & 42 & 14 & 44 \\
\hline 6.1. Combretum molle-Setaria lindenbergiana-Brachylaena rotundata sub-community & 4 & 1.5 & 0.8 & 14 & 3 & 30 \\
\hline 6.2. Combretum molle-Setaria lindenbergiana-Diplorhynchus condylocarpon sub-community & 4 & 1.5 & 0.8 & 34 & 29 & 49 \\
\hline 7.1. Perotis patens-Burkea africana-Fadogia homblei sub-community & 6 & 1.5 & 0.5 & 43 & 23 & 43 \\
\hline 7.2. Perotis patens-Burkea africana Gardenia volkensii sub-community & 6 & 1 & 0.8 & 64 & 13 & 33 \\
\hline 8. Kirkia wilmsii-Buxus macowanii forest & 7 & 2 & 0.5 & 35 & 60 & 12 \\
\hline 10.1. Cyperus albostriatus-Podocarpus latifolius-Rothmannia capensis sub-community & 14 & 2 & 1.3 & 67 & 36 & 20 \\
\hline 10.2. Cyperus albostriatus-Podocarpus latifolius-Widdringtonia nodiflora sub-community & 9 & 1.3 & 0.5 & 78 & 22 & 10 \\
\hline 11.1. Syzygium cordatum-Ischaemum fasciculatum-Schoenplectus corymbosus sub-community & 5 & 2 & 2 & 80 & 60 & 60 \\
\hline 11.2. Syzygium cordatum-Ischaemum fasciculatum-Osmunda regalis sub-community & 7 & 2 & 1.5 & 50 & 38 & 45 \\
\hline 12.1. Diplachne fusca-Fuirena pubescens-Aristida junciformis sub-community & - & - & 1.5 & - & - & 75 \\
\hline 12.2. Diplachne fusca-Fuirena pubescens-Drosera madagascariensis sub-community & - & - & 0.5 & - & - & 85 \\
\hline
\end{tabular}

species recorded and is divided into the following two subcommunities.

\section{Themeda triandra-Senegalia caffra-Eragrostis curvula sub-community}

This woodland sub-community is situated on plateau areas and midslopes (slope $4^{\circ}-16^{\circ}$ ) of Marakele. The altitude ranges from 1300 mamsl to 1600 mamsl. Rock cover is $10 \%$ - $35 \%$ and comprises large boulders and loose rocks. This community is associated with the Ib280 land type and occurs mostly on the Mispah soil form that is shallow with the soil depth of less than $150 \mathrm{~mm}$ (see Table 1).

Species from species group B characterise this subcommunity. The following are the important species as determined from the synoptic table analysis:

- Diagnostic species: None

- Constant species: Pearsonia cajanifolia, Raphionacme burkei, Senegalia caffra, Setaria sphacelata, Themeda triandra, Trachypogon spicatus

- Dominant species: Senegalia caffra, Setaria sphacelata, Themeda triandra

The shrub Dombeya rotundifolia (species group V) and the grasses Melinis repens (species group V), Melinis nerviglumis (species group I) and Heteropogon contortus (species group T) are prominent locally. The tree $(4 \mathrm{~m}$ tall $)$ and herbaceous layers ( $0.8 \mathrm{~m}$ tall) are well developed and the most prominent layers in this sub-community covering $80 \%$ and $70 \%$, respectively. The shrub layer $(1.1 \mathrm{~m}$ tall) is poorly developed with a cover of $19 \%$ (see Table 2 ).

\section{Themeda triandra-Senegalia caffra-Eragrostis chloromelas sub-community}

This woodland sub-community is situated on the northern to north-eastern lower midslopes and plateaus of the mountainous areas of Marakele. The altitude ranges from 1163 mamsl to 1420 mamsl with the steepness of the slopes from $4^{\circ}$ to $23^{\circ}$. This woodland sub-community is covered with medium to large boulders and large rocks with an approximate $36 \%$ coverage. This sub-community is associated with the Ib280 land type and occurs mostly on the Hutton soil form that ranges in depth from $400 \mathrm{~mm}$ to 1200 mm (see Table 1).

Species from species group C characterise this subcommunity. The following are the important species as determined from the synoptic table analysis:

- Diagnostic species: None

- Constant species: Asparagus transvaalensis, Bewsia biflora, Elionurus muticus, Eragrostis racemosa, Melinis repens, Raphionacme divaricatum, Senegalia caffra, Setaria sphacelata, Themeda triandra, Vangueria infausta

- Dominant species: Faurea saligna, Senegalia caffra, Themeda triandra

The tree layer is $5 \mathrm{~m}$ tall and covers $53 \%$ and is the most prominent layer in this sub-community, whereas the shrub and herbaceous layers (1.1 $\mathrm{m}$ and $0.8 \mathrm{~m}$ tall) are not well developed with relatively low cover of $15 \%$ and $29 \%$, respectively (see Table 2).

This sub-community is divided into two variants:

- Themeda triandra variant: This variant is characterised by the absence of species from species group D (characteristic species for variant 1.2.2) and include species such as the tree Lannea discolor (species group $\mathrm{N}$ ), the grass Heteropogon contortus (species group T), the grass Themeda triandra (species group V) and the tree Vangueria infausta (species group V). 
- Triumfetta sonderi variant: This variant is characterised by the presence of species from species group D. The shrub Ozoroa paniculosa (species group O), the grasses Eragrostis racemosa (species group V), Aristida meridionalis and the forbs Triumfetta sonderi (species group D) and Pseudopegolettia tenella (species group L) are locally prominent within this variant.

\section{Tristachya leucothrix-Protea welwitschii shrubland}

This community occurs in the eastern section of Marakele (see Figure 2) and occurs on footslope at altitudes ranging from 1480 mamsl to 1500 mamsl. The slope varies from $1^{\circ}$ to $5^{\circ}$ and no rocks are present. This shrubland is associated with the Ib286 land type and occurs mostly on Hutton soil form that ranges in depth from $400 \mathrm{~mm}$ to $1200 \mathrm{~mm}$ (see Table 1).

Species from species group E characterise this community. The following are the important species as determined from the synoptic table analysis:

- Diagnostic species: Cymbopogon caesius, Cynodon dactylon, Dicoma zeyheri, Elephantorrhiza elephantina, Eragrostis plana, Gladiolus pretoriensis, Lasiosiphon kraussianus, Helichrysum coriaceum, Hyparrhenia hirta, Protea welwitschii, Schizocarphus nervosus, Senecio coronatus, Triraphis andropogonoides, Tristachyaleucothrix, Hilliardiella aristata, Selago densiflora

- Constant species: Aeschynomene rehmannii, Anthospermum hispidulum, Aristida congesta subsp. congesta, Brachiaria serrata, Eragrostis capensis, Eragrostis gummiflua, Eragrostis racemosa, Helichrysum kraussii, Heteropogon contortus, Hypoxis obtusa, Melinis repens, Parinari capensis, Pygmaeothamnus zeyheri, Themeda triandra, Thesium utile, Trachypogon spicatus, Urelytrum agropyroides

- Dominant species: Elephantorrhiza elephantina, Hyparrhenia hirta, Urelytrum agropyroides

Other species that are prominent in this community are the shrub Protea welwitschii (species group E), the dwarf shrub Parinari capensis (species group M), the grasses Tristachya leucothrix, Cynodon dactylon and the forb Lasiosiphon kraussianus (species group E). A total number of 77 plant species was recorded for this community.

This community has a sparse vegetation cover with the shrub and herbaceous layers covering $10 \%$ and $18 \%$, respectively. The shrub layer has an average height of $0.8 \mathrm{~m}$ whilst the herbaceous layer is $1 \mathrm{~m}$ tall (see Table 2).

\section{Monocymbium ceresiiforme-Andropogon schirensis grassland}

This community is situated on the plateaus of the mountainous areas of Marakele (see Figure 2). Altitude ranges 1300 mamsl - 1600 mamsl and slopes are gentle to moderate $\left(4^{\circ}-16^{\circ}\right)$. Rock cover is $10 \%-75 \%$ and occurs as loose rocks and boulders.
Species from species group $F$ are characteristic of this grassland. The grasses Monocymbium ceresiiforme (species group F), Loudetia simplex and Eragrostis racemosa (species group V) and the tree Englerophytum magalismontanum (species group U) dominate the herbaceous and woody layers, respectively. This plant community has a total of 129 plant species recorded and is divided into the following two sub-communities:

\section{Monocymbium ceresiiforme-Andropogon schirensis- Protea gaguedi sub-community}

This shrubland sub-community occurs on the high mountain plateau in the southern section of Marakele at an altitude from 1620 mamsl to 1690 mamsl with the slope not exceeding $2^{\circ}$. It is covered with large rocky sheets with a cover of $20 \%$ $-35 \%$. This sub-community is associated with the Ad20 land type and occurs predominantly on Mispah and Glenrosa soil forms that are from $100 \mathrm{~mm}$ to $600 \mathrm{~mm}$ deep (see Table 1).

Species from species group $G$ are characteristic of this subcommunity. The following are the important species as determined from the synoptic table analysis:

- Diagnostic species: Cleome maculata, Cyanotis speciosa, Cyperus rupestris, Thunbergia atriplicifolia

- Constant species: Andropogon schirensis, Anthospermum hispidulum, Aristida transvaalensis, Bulbine burchellii, Commelina africana, Eragrostis racemosa, Fadogia homblei, Indigofera mollicoma, Loudetia simplex, Melinis repens, Parinari capensis, Pygmaeothamnus zeyheri, Schizachyrium sanguineum, Sphenostylis angustifolia, Trachypogon spicatus

- Dominant species: Andropogon schirensis

The shrub Protea gaguedi (species group G) and the grasses Loudetia simplex, Eragrostis racemosa (species group V) and Aristida transvaalensis (species group U) are prominent throughout this sub-community. The rocky sheet cover has resulted in a low vegetation cover with a sparse shrub layer covering only $3 \%$ and the herbaceous layer 30\% of the area. The dwarf shrub layer has an average height of $0.8 \mathrm{~m}$ compared to the taller grasses that are $1 \mathrm{~m}$ tall (see $\approx$ Table 2).

\section{Monocymbium ceresiiforme-Andropogon schirensis- Helichrysum kraussii sub-community}

The Monocymbium ceresiiforme-Andropogon schirensisHelichrysum krausii sub-community is situated on the southern section of the high mountain plateau at a higher altitude than the Monocymbium ceresiiforme-Andropogon schirensis-Protea gaguedi sub-community. The altitude ranges from 1640 mamsl to 2000 mamsl. The slope does not exceed $3^{\circ}$, and the rock cover is $30 \%-65 \%$ consisting of rocky outcrops. This sub-community is associated with the Fa286 and Ib310 land types and occurs predominantly on rock or the Mispah soil form that is $100 \mathrm{~mm}$ to $600 \mathrm{~mm}$ deep (see Table 1).

Species from species group $\mathrm{H}$ are characteristic of this sub-community. The following are the important species as determined from the synoptic table analysis: 
- Diagnostic species: None

- Constant species: Acalypha angustata, Andropogon schirensis, Anthospermum hispidulum, Bulbine burchellii, Dicoma anomala, Eragrostis racemosa, Fadogia homblei, Helichrysum kraussii, Loudetia simplex, Monocymbium ceresiiforme, Trachypogon spicatus

- Dominant species: Andropogon schirensis, Loudetia simplex, Schizachyrium sanguineum

The grasses Monocymbium ceresiiforme (species group F), Eragrostis racemosa (species group V) and the forbs Dicoma anomala (species group F) and Helichrysum krausii (species group $\mathrm{H}$ ) are prominent throughout this sub-community. The woody layer (trees and shrubs) is not well developed and covers $\leq 2 \%$ of the area and can grow up to $3 \mathrm{~m}$ tall, whilst the herbaceous layer covers $23 \%$ and has an average height of $0.8 \mathrm{~m}$ (see Table 2).

\section{Indigofera mollicoma-Encephalartos eugene- maraisii shrubland}

This community occurs on the scarp of the mountainous areas of Marakele (see Figure 2). This shrubland community occurs on steep slopes $\left(3^{\circ}-30^{\circ}\right)$ at altitudes ranging from 1160 mamsl to 1785 mamsl. Rocky outcrops cover $25 \%-70 \%$ of the area. This community is associated with the Fa286 land type with shallow (100 mm - $300 \mathrm{~mm}$ ) Mispah soil form dominant (see Table 1).

Species from species group I are characteristic of this community. The following are the important species as determined from the synoptic table analysis:

- Diagnostic species: None

- Constant species: Andropogon schirensis, Diheteropogon amplectens, Eragrostis racemosa, Loudetia simplex, Panicum natalense

- Dominant species: Andropogon schirensis, Combretum apiculatum, Cyperus leptocladus, Diheteropogon amplectens, Elephantorrhiza burkei, Encephalartos eugene-maraisii, Loudetia simplex, Protea caffra, Trachypogon spicatus

This community is characterised by the presence of the endangered Waterberg cycad, Encephalartos eugene-maraisii (species group I), which occurs in selected areas within this community. The tree Heteropyxis natalensis (species group Y), the shrub Protea caffra (species group M) and the grasses Themeda triandra, Loudetia simplex and Trachypogon spicatus (species group V) dominate the herbaceous layer in the areas where Encephalartos eugene-maraisii occurs. The vegetation has a relatively high cover with the trees ( $5 \mathrm{~m}$ tall) covering $26 \%$, the shrubs ( $2 \mathrm{~m}$ tall) covering $13 \%$ and the herbaceous layer (1.8 m tall) covering $43 \%$ of the area (Table 2 ). This plant community has 126 plant species recorded.

\section{Tephrosia elongata-Protea caffra woodland}

This short woodland is found on moderate to steep, southern, south-eastern and south-western midslopes of the mountainous area of Marakele (Figure 2). The altitude ranges from
1240 mamsl to 1880 mamsl with large boulders, rocky sheets and rocks covering $20 \%-70 \%$ of the soil. This community is associated with the Ib310 land type and is associated with shallow (50 mm - $150 \mathrm{~mm}$ ) Mispah soil form (see Table 1).

Species from species group $\mathrm{J}$ are characteristic of this community. The following are the important species as determined from the synoptic table analysis:

- Diagnostic species: Erica drakensbergensis, Kohautia amatymbica, Tephrosia elongata

- Constant species: Bulbine burchellii, Eragrostis racemosa, Loudetia simplex, Panicum natalense, Themeda triandra

- Dominant species: Englerophytum magalismontanum, Loudetia simplex, Monocymbium ceresiiforme, Panicum natalense, Podocarpus latifolius, Protea caffra, Rhynchosia nitens, Senecio venosus, Tephrosia elongata, Themeda triandra, Trachypogon spicatus, Urelytrum agropyroides

The shrub Searsia dentata (species group M), scandent shrub Searsia magalismontana (species group J), the grass Diheteropogon amplectens (species group U) and the forb Helichrysum setosum (species group J) are prominent within this community. A high number of 139 plant species was recorded in this community.

This community is divided into the following two subcommunities.

\section{Tephrosia elongata-Protea caffra-Gerbera viridifolia woodland sub-community}

This woodland sub-community is situated on steep $\left(16^{\circ}-32^{\circ}\right)$ southern, south-eastern and south-western midslopes of Marakele. The altitude ranges from 1240 mamsl to 1880 mamsl and large boulders, rocky outcrops and loose rocks cover $20 \%-70 \%$ of the area (see Table 1$)$. The tree ( $3 \mathrm{~m}$ tall), shrub (1.5 $\mathrm{m}$ tall) and herbaceous (1.6 $\mathrm{m}$ tall) layers have mean cover values of $13 \%, 7 \%$ and $36 \%$, respectively (see Table 2).

The characteristic species include the grass Cymbopogon pospischilii and the forbs Scabiosa columbaria, Becium obovatum, Gerbera viridifolia and Berkheya zeyheri (species group K).

\section{Tephrosia elongata-Protea caffra-Brachiaria serrata sub-community}

The Brachiaria serrata-Protea caffra sub-community is found on the higher midslopes (3) of the mountainous areas of Marakele. The gradient ranges from $20^{\circ}$ to $31^{\circ}$ and the altitude from 1470 mamsl to 1880 mamsl. The area comprises large- to medium-sized rocks covering $40 \%$ - $70 \%$ of the area with the vegetation growing between the rocks (see Table 1). The tree ( $3 \mathrm{~m}$ tall), shrub (1.8 $\mathrm{m}$ tall) and herbaceous ( $0.8 \mathrm{~m}$ tall) layers have mean cover values of $42 \%, 14 \%$ and $44 \%$, respectively (see Table 2 ).

Species from species group L are characteristic for this subcommunity and include the grasses Brachiaria serrata, Aristida aequiglumis, Cymbopogon validus and the forbs Pseudopegolettia 
tenella, Polygala uncinata, Athrixia elata, Berkheya insignis, Castalis spectabilis and Helichrysum cephaloideum.

\section{Combretum molle-Setaria lindenbergiana woodland}

This woodland is situated on moderate-to-steep midslopes at an altitude of 1360 mamsl - 1620 mamsl with large- and medium-sized rocks covering $7 \%-80 \%$ of the area (Figure 2 ). This community is associated with Fa286 and Ib305 land types and is associated with moderately deep (50 mm - $600 \mathrm{~mm}$ ) Mispah soil form (see Table 1). Species from species group $\mathrm{N}$ are characteristic of this woodland community. The tree Vangueria infausta and the grasses Setaria lindenbergiana (species group N), Trachypogon spicatus (species group V) and Diheteropogon amplectens (species group U) dominate the woody and herbaceous layers, respectively. This plant community has the highest species richness with 155 different plant species recorded.

This community is divided into the following two subcommunities:

\section{Combretum molle-Setaria lindenbergiana-Brachylaena rotundata sub-community}

This short open woodland sub-community is situated on the steep north-eastern and south-western midslopes $\left(20^{\circ}-33^{\circ}\right)$ of the mountainous areas of Marakele Altitude ranges from 1400 mamsl to 1540 mamsl with large- and medium-sized rocks covering $7 \%-45 \%$ of the area.

Species from species group $\mathrm{O}$ are characteristic of this sub-community. The following are the important species as determined from the synoptic table analysis:

- Diagnostic species: None

- Constant species: Andropogon schirensis, Asparagus transvaalensis, Burkea africana, Combretum molle, Commelina africana, Cyperus leptocladus, Elephantorrhiza burkei, Englerophytum magalismontanum, Heteropyxis natalensis, Ozoroa paniculosa, Pellaea calomelanos, Phyllanthus parvulus, Rhoicissus revoilii, Setaria lindenbergiana, Vangueria infausta

- Dominant species: Andropogon schirensis, Diheteropogon amplectens, Elephantorrhiza burkei, Heteropyxis natalensis, Protea caffra, Setaria lindenbergiana

The trees have an average height of $4 \mathrm{~m}$, shrubs $1.5 \mathrm{~m}$ and the herbaceous layer $0.8 \mathrm{~m}$. The cover of the woody layer (trees and shrubs) is less than $14 \%$ and the herbaceous layer $30 \%$ (see Table 2).

\section{Combretum molle-Setaria lindenbergiana-Diplorhynchus condylocarpon sub-community}

This sub-community occurs on moderate-to-steep $\left(11^{\circ}-30^{\circ}\right)$ midslopes (3) at an altitude that ranges from 1038 mamsl to 1620 mamsl. A total of 22 relevés were recorded of which seven were new relevés recorded on the newly acquired land. Large- to medium-sized rocks and boulders as well as loose rock occur in this sub-community with a rock cover of $25 \%-80 \%$.
Species from species group $\mathrm{P}$ are characteristic of this subcommunity. The following are the important species as determined from the synoptic table analysis:

- Diagnostic species: Diplorhynchus condylocarpon

- Constant species: Burkea africana, Combretum molle, Commelina africana, Englerophytum magalismontanum, Pellaea calomelanos, Setaria lindenbergiana, Vangueria infausta

- Dominant species: Andropogon schirensis, Brachiaria serrata, Burkea africana, Combretum apiculatum, Combretum molle, Croton gratissimus, Diplorhynchus condylocarpon, Elephantorrhiza burkei, Heteropogon contortus, Ochna pulchra, Pseudolachnostylis maprouneifolia, Schizachyrium sanguineum, Setaria lindenbergiana

The tall shrub Diplorhynchus condylocarpon (species group P) is diagnostic for this sub-community and occurs exclusively in this sub-community. The shrub Ochna pulchra (species group N) and the grasses Aristida scabrivalvis (species group P), Brachiaria serrata (species group L) and the tree Pseudolachnostylis maprouneifolia (species group $\mathrm{N}$ ) are prominent throughout this community. The vegetation has a moderate to high cover with the trees ( $4 \mathrm{~m}$ tall) covering $34 \%$, the shrubs ( $1.5 \mathrm{~m}$ tall) covering $29 \%$ and the herbaceous layer (0.8 m tall) covering 49\% (see Table 2).

\section{Perotis patens-Burkea africana woodland}

This woodland is situated on the midslopes and plateaus of the mountainous areas in Marakele. Species from species group $\mathrm{Q}$ are characteristic of this woodland community (see Figure 2). The tree Burkea africana (species group T) and the grasses Setaria sphacelata (species group V), Heteropogon contortus (species group $\mathrm{T}$ ) and Schizachyrium sanguineum (species group U) dominate the woody and herbaceous layers, respectively. This plant community has a total of 150 plant species and has the second highest species richness and has one of the highest cover of all the plant communities. This community is divided into the following two sub-communities:

\section{Perotis patens-Burkea africana-Fadogia homblei sub- community}

This tall shrubland sub-community is situated on the southern and north-eastern midslopes and plateaus of Marakele. The slope ranges from $2^{\circ}$ to $23^{\circ}$ and altitude from 1180 mamsl to 1500 mamsl with no rock cover on the plateaus to a rock cover of $60 \%-70 \%$ on the midslopes. The subcommunity is associated with the Ib305 land type with moderately deep (50 mm - $600 \mathrm{~mm}$ ) soil of the Mispah and Hutton soil forms (see Table 1).

Species from species group $\mathrm{R}$ are characteristic of this subcommunity. The following are the important species as determined from the synoptic table analysis:

- Diagnostic species: None

- Constantspecies:Burkea africana, Faurea saligna, Schizachyrium sanguineum, Senecio venosus

- Dominant species: Burkea africana, Calpurnia aurea, Hypoestes forskaolii 
The tree Faurea saligna (species group A), the grasses Heteropogon contortus (species group T), Andropogon schirensis (species group V) and the forb Fadogia homblei (species group $\mathrm{U})$ are prominent throughout this sub-community. The tree layer is tall (6 $\mathrm{m}$ tall) and together with the herbaceous layer ( $0.8 \mathrm{~m}$ tall) covers $43 \%$ each of the area. The shrubs are $1.5 \mathrm{~m}$ tall and cover $23 \%$ (see Table 2 ).

\section{Perotis patens-Burkea africana-Gardenia volkensii sub-community}

This tall woodland sub-community is found on the lower midslopes (3) and plateaus (1) with a slope of $1^{\circ}-7^{\circ}$ at an altitude that of 1150 mamsl - 1400 mamsl. Rock cover $5 \%-70 \%$ of the area. Mispah and Hutton soil forms are characteristic whilst the vegetation is associated with the Fa286 land type with moderate deep (50 mm - $600 \mathrm{~mm}$ ) soil of the Mispah and Clovelly soil forms (see Table 1).

Species from species group $S$ are characteristic of this subcommunity. The following are the important species as determined from the synoptic table analysis:

- Diagnostic species: None

- Constant species: Heteropogon contortus, Pellaea calomelanos, Rhoicissus revoilii

- Dominant species: Andropogon schirensis, Burkea africana, Combretum apiculatum, Heteropogon contortus, Setaria sphacelata, Themeda triandra

The grasses Schizachyrium sanguineum (species group U), Eragrostis curvula (species group B) and the forb Kohautia cynanchica (species group I) are prominent locally. This subcommunity has a well-developed tree layer that is $6 \mathrm{~m}$ tall covering $64 \%$ of the area, whilst the shrub layer ( $1 \mathrm{~m}$ tall) is not well developed and covers 13\%. The herbaceous layer consists of medium tall grasses $(0.8 \mathrm{~m}$ tall) that cover $33 \%$ of the area (see Table 2).

\section{Kirkia wilmsii-Buxus macowanii forest}

The tall forest community is restricted to relatively high, hot, dry ravine areas on steep midslopes (slope $2^{\circ}-29^{\circ}$ ) in Marakele (see Figure 2). The altitude varies from 1110 mamsl to 1265 mamsl. Rocks cover $40 \%-60 \%$ of the area. This community is associated with the $\mathrm{Ib} 305$ land type with shallow $(10 \mathrm{~mm}-300 \mathrm{~mm}$ ) soil of the Mispah soil form (see Table 1).

Species from species group W are characteristic of this community. The following are the important species as determined from the synoptic table analysis:

- Diagnostic species: Buxus macowanii, Croton gratissimus, Kirkia wilmsii, Pouzolzia mixta

- Constant species: Cheilanthes viridus, Cryptolepis transvaalensis, Mimusops zeyheri, Olea europaea subsp. cuspidata, Pellaea calomelanos

- Dominant species: Buxus macowanii, Kirkia wilmsii, Mimusops zeyheri
The trees Olea europaea subsp. cuspidata (species group Y), Berchemia zeyheri, Ficus thonningii (species group W) and the woody climber Cryptolepis transvaalensis (species group Y) are prominent within this community. The tree (7 $\mathrm{m}$ tall), shrub ( $2 \mathrm{~m}$ tall) and herbaceous (0.5 $\mathrm{m}$ tall) layers have a mean cover of $35 \%, 60 \%$ and $12 \%$, respectively (see Table 2 ). A total number of 58 different plant species was recorded for this community.

\section{Diospyros whyteana-Calodendron capense forest}

This tall forest is found on midslopes with steep $\left(3^{\circ}-30^{\circ}\right)$, dry ravines of the western mountainous section in Marakele, at an altitude of 1180 mamsl - 1530 mamsl (see Figure 2). Rock cover is $>80 \%$ where rockslides occurred in the past; however, an important variant, with the same plant species composition, occurs on the floodplain (4) where four drainage lines converse with water always present at the confluence. The alluvial Dundee soil form is deeper than $>1.2 \mathrm{~m}$ and with no rocks present. This community is located within the Ib305 land type (see Table 1).

Species from species group $X$ are characteristic of this community. The following are the important species as determined from the synoptic table analysis:

- Diagnostic species: None

- Constant species: Diospyros whyteana, Mimusops zeyheri

- Dominant species: Calodendron capense, Calpurnia aurea, Chaetacanthus aristata, Combretum moggii, Diospyros whyteana, Gymnosporia polyacantha, Hypoestes forskaolii, Maytenus undata, Mimusops zeyheri, Nuxia congesta, Obetia tenax, Olea europaea subsp. cuspidata, Podocarpus latifolius, Strychnos usambarensis, Tetradenia brevispicata, Trema orientalis, Tricalysia lanceolata

The trees Celtis africana (species group X), Pappea capensis (species group Y), Syzygium guineense (species group AC) and the shrubs Grewia occidentalis (species group X) and Cryptolepis transvaalensis (species group $\mathrm{Y}$ ) are prominent within this community. The woody layer is dominant and well developed with the tree layer (10 m tall) covering 65\%, the shrubs ( $2 \mathrm{~m}$ tall) covering $42 \%$. As expected, because of the dense woody layer, the herbaceous layer is sparse and short $(1 \mathrm{~m}$ tall) and covers $23 \%$ (see Table 2). Compared to the other plant communities, this plant community has a moderate species richness with 86 different plant species recorded.

\section{Cyperus albostriatus-Podocarpus latifolius forest}

This forest is situated on moderate to steep midslopes at altitudes of 1380 mamsl - 1730 mamsl. Species from species group $\mathrm{Z}$ are characteristic of this forest community (see Figure 2). The trees Podocarpus latifolius, Curtisia dentata, the small shrub Myrsine africana and the forb Cyperus albostriatus (species group Z) dominate the woody and herbaceous layers, respectively. With a total of 57 different plant species recorded, this plant community has a low species richness. This community is divided into the following two sub-communities: 


\section{Cyperus albostriatus-Podocarpus latifolius-Rothmannia capensis sub-community}

The Cyperus albostriatus-Podocarpus latifolius-Rothmannia capensis sub-community is situated on gentle to steep, north, northeast and northwest facing midslopes $\left(4^{\circ}-22^{\circ}\right)$ at an altitude of 1380 mamsl - 1660 mamsl. Rocks cover from $60 \%$ to $80 \%$ of the area and consist of large blocks, boulders and loose rocks. This tall forest occurs in the Ib305 land type with the Mispah soil form that ranges from $10 \mathrm{~mm}$ to $300 \mathrm{~mm}$ deep (see Table 1).

Species from species group AA are characteristic for this subcommunity. The following are the important species as determined from the synoptic table analysis:

- Diagnostic species: Tetradenia brevispicata

- Constant species: Curtisia dentata, Diospyros whyteana, Myrsine africana, Podocarpus latifolius, Rothmannia capensis

- Dominant species: Diospyros whyteana, Myrsine africana, Pittosporum viridiflorum, Podocarpus latifolius, Pterocelastrus echinatus

The tree Ilex mitis, the scandent shrub Secamone alpini and the forb Cyperus albostriatus (species group Z) are present throughout this sub-community. The tree layer is very tall (14 $\mathrm{m}$ tall) and well developed with a canopy cover of $67 \%$, whereas the shrub layer is $2 \mathrm{~m}$ tall and covers $36 \%$. The herbaceous layer is relatively tall $(1.3 \mathrm{~m})$ and covers $20 \%$ of the area (see Table 2).

\section{Cyperus albostriatus-Podocarpus latifolius-Widdringtonia nodiflora sub-community}

The Cyperus albostriatus-Podocarpus latifolius-Widdringtonia nodiflora sub-community is situated on moderate to steep, south and east facing midslopes (3) (slope $6^{\circ}-22^{\circ}$ ) in Marakele at an altitude of 1500 mamsl - 1730 mamsl. This tall forest community occurs along perennial watercourses in the protected, moist ravines of the mountainous areas of Marakele. Because of the high percentage rock cover and poor herbaceous layer, this forest community is protected from fire. Rocks cover from $65 \%$ to $85 \%$ of the area. This community occurs on the Ib305 land type associated with the shallow (10 mm - $300 \mathrm{~mm}$ ) Mispah soil form (see Table 1).

Species from species group $\mathrm{AB}$ are characteristic for this subcommunity. The following are the important species as determined from the synoptic table analysis:

- Diagnostic species: Blechnum attenuatum, Phylica paniculata, Widdringtonia nodiflora

- Constant species: Cyperus albostriatus, Myrsine africana, Podocarpus latifolius

- Dominant species: Blechnum attenuatum, Widdringtonia nodiflora

The trees Pittosporum viridiflorum (species group AB), Ilex mitis, the scandent shrub Secamone alpini (species group Z) and the fern Pteridium aquilinum (species group $\mathrm{AB}$ ) are prominent within this community. The tall tree layer $(9 \mathrm{~m})$ has a $78 \%$ cover, the shrubs $(1.3 \mathrm{~m}$ tall $)$ cover $22 \%$ and the short herbaceous layer $(0.5 \mathrm{~m})$ covers $10 \%$ (see Table 2 ).

\section{Syzygium cordatum-Ischaemum fasciculatum woodland}

This woodland is situated along the upper reaches of the Matlabas River in Marakele (see Figure 2). Species from species group AC are characteristic for this woodland community. The trees Syzygium cordatum, S. guineense and the grasses Ischaemum fasciculatum, Andropogon eucomus and Phragmites australis (species group AC) dominate the woody and herbaceous layers, respectively. This plant community has a moderate plant species richness with 75 plant species identified and is divided into the following two sub-communities:

\section{Syzygium cordatum-Ischaemum fasciculatum- Schoenoplectus corymbosus sub-community}

The Syzygium cordatum-Ischaemum fasciculatum-Schoenoplectus corymbosus sub-community occurs along the floodplains (4) of the Matlabas River at an altitude of 1036 mamsl - 1320 mamsl with the slope not $>3^{\circ}$. Rocks cover from $10 \%$ to $48 \%$ of the area with most of the rocks forming part of the riverbed. This sub-community is associated with the Fa286 land type with deep (> $1200 \mathrm{~mm}$ ) Hutton, Clovelly and Avalon soil forms (see Table 1).

Species from species group AD are characteristic of this subcommunity. The following are the important species as determined from the synoptic table analysis:

- Diagnostic species: Pseudognaphalium luteo-album, Schoenoplectus corymbosus

- Constant species: Ischaemum fasciculatum, Miscanthus junceus, Syzygium cordatum

- Dominant species: Ischaemum fasciculatum, Miscanthus junceus, Phragmites australis, Pseudognaphalium luteoalbum, Syzygium cordatum

The sedges Xyris capensis and Cyperus leptocladus (species group AI) are present throughout this sub-community. The woody layer in this riverine vegetation is well developed with trees ( $5 \mathrm{~m}$ tall) covering $80 \%$, shrubs ( $2 \mathrm{~m}$ ) covering $60 \%$ and the herbaceous layer $(2 \mathrm{~m})$ covering $60 \%$ of the area (see Table 2).

\section{Syzygium cordatum-Ischaemum fasciculatum-Osmunda regalis sub-community}

The Osmunda regalis-Syzygium guineense woodland is found on floodplains along the fast-flowing upstream tributaries of the Matlabas River (5) at an altitude of 1036 mamsl - 1420 mamsl with the slope not exceeding $2^{\circ}$. Because of the higher altitude and narrower streambeds, the rock cover is higher, viz. $40 \%-90 \%$ and consists of large blocks and boulders along as well as in the streambed. This sub-community is associated with the Fa286 land type with deep (> $1200 \mathrm{~mm}$ ) Hutton, Clovelly and Avalon soil forms (see Table 1).

Species from species group AE are characteristic for this subcommunity. The following are the important species as determined from the synoptic table analysis:

- Diagnostic species: Osmunda regalis, Setaria pallide-fusca 
- Constant species: Cyperus leptocladus, Ischaemum fasciculatum, Miscanthus junceus, Syzygium cordatum, Xyris capensis

- Dominant species: Ilex mitis, Ischaemum fasciculatum, Miscanthus junceus, Osmunda regalis, Phragmites australis, Syzygium cordatum, Syzygium guineense

The tree, shrub and grass layers cover 50\%, 38\% and 45\%, respectively, with the trees $7 \mathrm{~m}$ tall, the shrubs $2 \mathrm{~m}$ tall and the herbaceous layer $1.5 \mathrm{~m}$ tall (see Table 2).

\section{Leptochloa fusca-Fuirena pubescens forbland}

The Leptochloa fusca-Fuirena pubescens forbland occurs in the waterlogged and seasonal waterlogged sponges (wetlands) in the eastern and southern high mountain catchment areas of the Matlabas-, Sterkstroom- and Sondags rivers (see Figure 2). Species from species group AF are characteristic for this wetland community that has a low species richness of 50 plant species being recorded and is divided into the following two sub-communities.

\section{Leptochloa fusca-Fuirena pubescens-Aristida junciformis sub-community}

The Leptochloa fusca-Fuirena pubescens-Aristida junciformis sub-community is situated as waterlogged to seasonal waterlogged sponges (5) in the southern section of the mountainous catchments area of the Matlabas River. This sub-community occurs at an altitude that ranges from 1460 mamsl to 1480 mamsl, with the slope not exceeding $5^{\circ}$. No rocks are present in this sub-community. The vegetation occurs in the Ib310 land type with moderately deep (100 mm - $600 \mathrm{~mm}$ ) soil belonging to the Mispah and Oakleaf soil forms (see Table 1).
Species from species group AG are characteristic for this sub-community. The following are the important species as determined from the synoptic table analysis:

- Diagnostic species: Arundinella nepalensis, Ascolepis capensis, Berkheya radula, Carex cernua, Cyperus denudatus, Leptochloa fusca, Eriochrysis pallida, Helichrysum epapposum, Pennisetum sphacelatum, Pycnostachys reticulata

- Constant species: Andropogon huillensis, Aristida junciformis, Cyperus leptocladus, Fuirena pubescens

- Dominant species: Aristida junciformis, Cyperus denudatus, Leptochloa fusca, Fuirena pubescens, Miscanthus junceus, Xyris capensis

There are no woody species, and the herbaceous layer is 1.5 $\mathrm{m}$ tall covering $75 \%$ of the area (see Table 2 ).

\section{Leptochloa fusca-Fuirena pubescens-Drosera madagascariensis sub-community}

This sub-community is situated in seasonal sponges on the eastern and southern section of Marakele that feed the Sterkstroom and Sondags rivers. It occurs at an altitude of 1420 mamsl with the slope not exceeding $3^{\circ}$. No rocks are present in this forbland sub-community. This community occurs in the Fa286 land type with Hutton, Clovelly, Katspruit and Avalon soil forms with the soil from $50 \mathrm{~mm}$ to $1200 \mathrm{~mm}$ deep (see Table 1).

Species from species group AH are characteristic for this subcommunity. The following are the important species as determined from the synoptic table analysis:

- Diagnostic species: Aristida bipartita, Chironia purpurescens, Cyperus denudatus, Cyperus thorncroftii, Dierama medium,

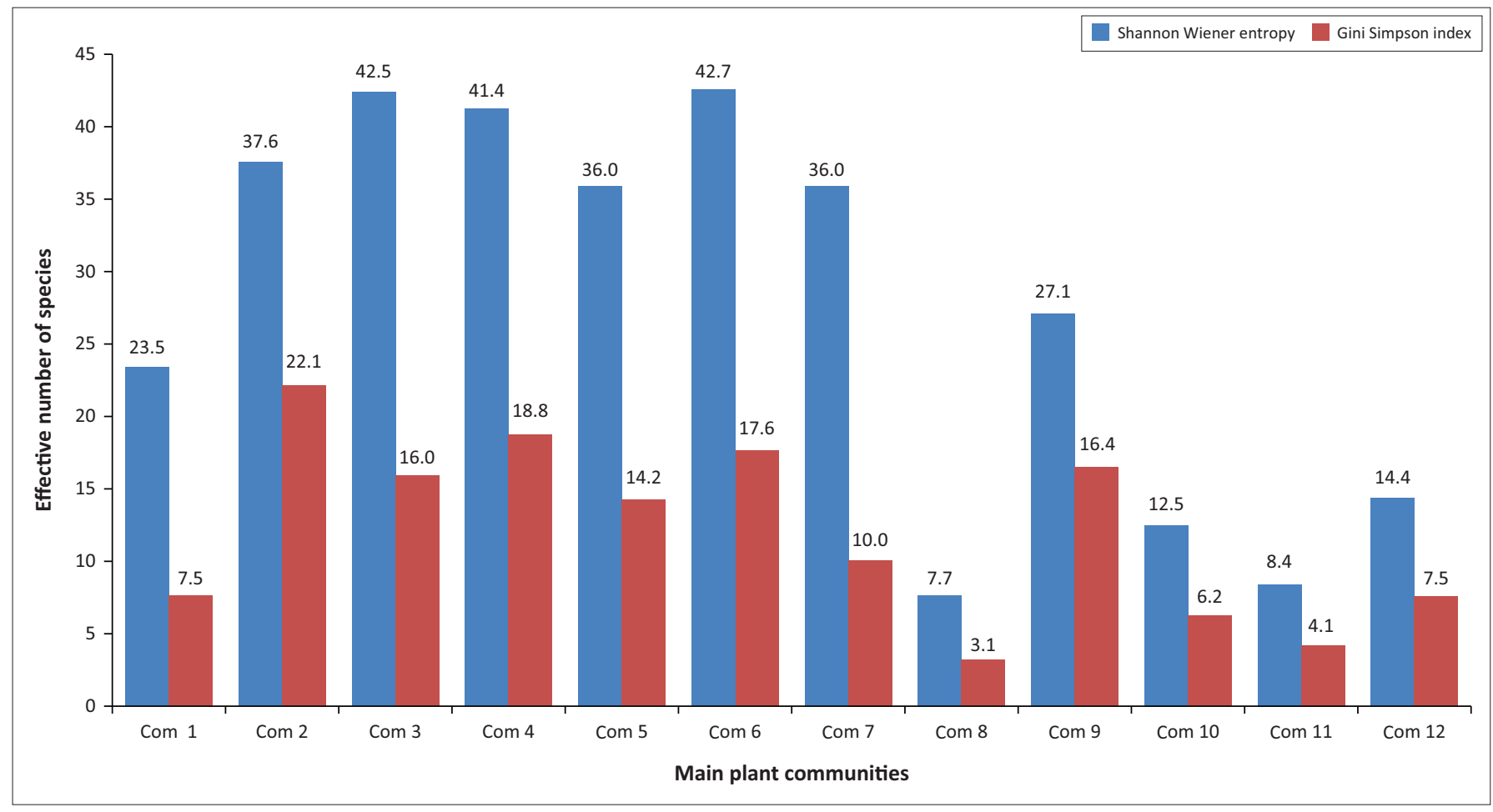

Com, community.

FIGURE 3: Species diversity (Shannon-Wiener \& Gini Simpson Index) for the main plant communities of the mountainous Waterberg section of Marakele National Park. 
Disa woodii, Drosera madagascariensis, Eragrostis inamoena, Helichrysum aureonitens, Kyllinga alba, Lobelia erinus, Monopsis decipiens, Panicum dregeanum, Senecio affinis, Senecio erubescens, Senecio polyodon, Verbena bonariensis

- Constant species: Andropogon huillensis, Fuirena pubescens, Hypericum lalandii, Kohautia virgata, Xyris capensis

- Dominant species: Fuirena pubescens, Hypericum lalandii, Monopsis decipiens, Xyris capensis

There are no woody species with the herbaceous layer $0.5 \mathrm{~m}$ tall covering $85 \%$ of the area (see Table 2 ).

Plant communities 3, 4 and 6 have the highest diversity followed by plant communities 2, 5 and 7 . Plant community 6 has the highest species richness (155) followed by plant community 7 with 150 species. Plant communities 8, 10, 11 and 12 have the lowest diversity and also the lowest species richness of 58, 57, 75 and 50 species, respectively (see Figures 2 \& 3).

\section{Discussion}

This study resulted in the identification and classification of 16 sub-communities and two variants that can be grouped into 12 main plant communities.

Based on the topography, plant species composition and vegetation structure the vegetation can be grouped into five major groups, namely the: (1) lower midslope and plateau shrub- and woodlands, (2) high altitude midslope woodland, (3) high-lying plateau and midslope grass-, shrub- and woodlands, (4) ravine, footslope and drainage line forests and woodland and (5) higher-lying plateau wetlands and forblands.

The lower midslope and plateau shrub and woodlands group is represented by the Themeda triandra-Senegalia caffra woodland (1), the Tristachya leucothrix-Protea welwitschii shrubland (2) and the Perotis patens-Burkea africana woodland (7). These plant communities are located at low to medium altitudes on plateaus and lower midslopes with moderate slopes $\left(1^{\circ}-16^{\circ}\right)$. The soils are shallow to moderately deep with rock cover that varies from low to high (see Table 1). The plant communities belonging to this group have a moderate to high diversity and moderate species richness, indicating them to be stable with a high ecosystem functioning (Allan et al. 2011) (see Figure 3). The Themeda triandra-Senegalia caffra woodland (1) corresponds to the Acacia caffra-Setaria sphacelata Short Closed Woodland as described by Van Staden (2002) and Van Staden and Bredenkamp (2005). Elephants were introduced to Marakele National Park in 1996 and a monitoring study established that the impact of the elephants on this community is negligible (Van Staden et al. 2016).

The vegetation of the Tristachya leucothrix-Protea welwitschii shrubland (2) is characterised by several woody suffrutex species having traits that allow them to survive low temperatures and fires, which are prevalent on these lower plateaus and midslopes. The vegetation of this community shows affinity with similar plant communities in the bushveld area as described by Brown, Bredenkamp and Van Rooyen (1996) in the Borakalalo National Park.

The Perotis patens-Burkea africana woodland (7) consists of plateaus as well as steep slopes $\left(1^{\circ}-23^{\circ}\right)$ (see Figure 2 ). Animals tend to utilise the plateaus with deeper soil with palatable grass species often, and consequently some sections were heavily overgrazed in the past, which lead to degradation of the veld and created bare patches and erosion in some areas. Although this plant community has the second highest species richness, it has a moderate to high diversity (see Figure 3). The high species richness can be ascribed to the various pioneer species present in the degraded areas.

The high altitude midslope grass-, shrubland and woodland is represented by plant community 6 . The Combretum molleSetaria lindenbergiana woodland (6) occurs on steep upper midslopes (see Figure 2). The soils are shallow with moderate to high rock cover, consisting of large boulders and rocky sheets, covering $11 \%-80 \%$. This community has the highest diversity and species richness of all the communities in the study area (see Figure 3). The steep gradients helps to maintain this plant community in a very good to excellent condition because the steep gradient makes it difficult to be affected by wildlife. Fire plays a role to maintain the buildup of moribund material. This community has some similarity in terms of species composition with the Diplorhynchus condylocarpon-Combretum zeyheri woodland as described by Brown et al. (1996) in the Borakalalo National Park and the Combretum molle-Xerophyta retinervis open to closed woodland in the Loskopdam Nature Reserve (Filmalter 2010) and the Burkea africana-Diplorhynchus condylocarpon variation in Marakele National Park (Van Staden \& Bredenkamp 2005). All of these communities have a similar structure and species composition (see Online Appendix 1 \& Table 2).

The high-lying plateau and midslope grass-, shrub- and woodlands group is represented by plant communities 3, 4 and 5. The Monocymbium ceresiiforme-Andropogon schirensis grassland (3) is located on the plateaus on flat rocky plateaus with a high rock cover of $20 \%-45 \%$ on shallow sandy to sandy-loam soils (see Table 1). This group is typical of high altitude vegetation dominated by grasses with few woody species present. These high-lying areas are exposed to low temperatures and together with the large rocky outcrops provide suitable habitat for grass species. This group has affinity with the Protea gaguedi-Monocymbium ceresiiforme short open shrubland of the Rustenburg Nature Reserve as described by Coetzee (1975), the Monocymbium ceresiiformeLoudetia simplex grassland as described by Bredenkamp and Brown (2003) in the Bankenveld in Gauteng and shares species such as Eragrostis racemosa, Loudetia simplex, Parinari capensis, Pygmaeothamnus zeyheri, Aristida transvaalensis, Monocymbium ceresiiforme, Andropogon schirensis, Sphenostylis angustifolia and Trachypogon spicatus. The plant species 
composition of this group has affinity to Drakensberg vegetation and is typical of high-altitude cooler aspects although it can also occur on warmer north-facing highaltitude rocky slopes. This group has the second highest diversity and a high species richness (see Figure 3) that can be ascribed to the high altitude and little disturbance experienced by wildlife. This group is thought to be in a pristine condition.

The Indigofera mollicoma-Encephalartos eugene-maraisii shrubland (4) of this group is located at high altitudes on moderate to very steep midslopes with shallow soil and moderate to high rock cover (see Table 1 ). The vegetation is mostly high-altitude grassland and shrubland and as such exposed to low winter temperatures. The presence of the endangered Waterberg cycad, Encephalartos eugenemaraisii along steep scarp of this plant community makes this shrubland an important area from a management perspective to ensure the conservation of this species. It needs full sunlight and is adapted to hot summers and cold winters (Grobbelaar 2002). This plant community has high diversity and species richness indicating it to be in a pristine condition with a unique habitat for different species (see Figure 3).

The Tephrosia elongata-Protea caffra woodland (5) of this group is characterised by the dominance of especially the tall shrub Protea caffra. The plant community occurs at relatively high altitudes on moderate to steep midslopes with shallow soil and medium to high rock cover (Table 1). This community is similar to the Protea caffra-Rhus dentata Low Closed Woodland (Van Staden \& Bredenkamp 2005) as well as the Protea caffra-Loudetia simplex community of the Walter Sisulu Botanical Gardens (Behr \& Bredenkamp 1988), the Tristachya biseriata-Protea caffra Cool Temperate Mountain Bushveld and the Protea roupelliae Cool Mountain Bushveld of the Bankenveld as described by Bredenkamp and Brown (2003). The group occurs on steep and mostly southern midslopes with high rock cover and moist cool habitats and has affinity with Drakensberg vegetation. According to Scott (1982) and Partridge et al. (1993), certain interglacial periods in the Late and Middle Pleistocene provided opportunity for Afromontane (Drakensberg) vegetation to establish on the Magaliesberg and Waterberg. During the last Glacial Maximum, this vegetation became restricted because of aridification and survive only in protected mountain valleys in the interior of South Africa, including the Bankenveld. This group has a moderate-high diversity and species richness.

The grass, Themeda triandra, which is the dominant grass species in this group, is influenced by fire. During a season without fire in the mountainous areas, the occurrence of Themeda triandra is lower than just after an intensive fire in the mountainous areas and good rain. Themeda triandra is a decreaser grass species (Novellie \& Kraaij 2010) that is utilized well by animals in the mountainous areas of Marakele, especially after a fire.
The ravine, footslope and drainage line forests and woodland group are represented by plant communities 8, 9, 10 and 11 (Figure 2). The Kirkia wilmsii-Buxus macowanii forest (8) and the Diospyros whyteana-Calodendron capense forest (9) are located at low to high altitudes on flat to very steep, hot, dry ravine areas and represent the dry forests. The soils are shallow to deep, and the rock cover ranges from $0 \%$ to $80 \%$ (Table 1 ). The woody layer is well developed and dominates the vegetation. Trees range in height from $7 \mathrm{~m}$ to $10 \mathrm{~m}$, whilst the shrubs are approximately $1.5 \mathrm{~m}$ tall. Because of the dense canopies, dry conditions and variable rock cover, the herbaceous layer is not well developed and has a low canopy cover (Table 2). Similar ravine vegetation is found in other parts of the bushveld areas (Brown et al. 1996). These communities have a low-moderate diversity and species richness (Figure 3).

The Cyperus albostriatus-Podocarpus latifolius forest (10) of this group represents the wet forests on steep slopes mostly in protected ravines. The soils are shallow, and the rock cover ranges from $60 \%$ to $85 \%$ (Table 1). The Cyperus albostriatusPodocarpus latifolius-Widdringtonia nodiflora forest subcommunity (10.2) of this group is not utilised by wildlife, but fire plays an important role in the pattern and processes of it. Because of this area being a forest, there is a regular build-up of moribund leaf material. Unfortunately, hot fires occur in the surrounding plant communities every second year, which then escape into this sub-community (Van Staden 2002). As a result, the damage to the vegetation of this forest is extensive after each fire causing a decrease in woody species. If not effectively managed, it could lead to the encroachment of grass species that will increase fire damage to this forest subcommunity and could potentially lead to this sub-community disappearing. This plant community is similar to the Podocarpus latifolius-Rothmannia capensis Tall Forest described by Van Staden (2002), Mucina and Van Staden (2003), Van Staden and Bredenkamp (2006). Podocarpus latifolius is a protected tree in South Africa and the Limpopo province, which makes this plant community even more important.

The forest plant communities, including the termitaria bush clumps, were damaged when the elephants were introduced, but the impact on some of the forest communities changed when the northern section (Marakele Pty Ltd.), consisting mainly of valley bottomland and plains with more palatable plant species, was incorporated into Marakele and the elephants moved into that area (Van Staden et al. 2016). These termitaria bush clumps are susceptible to fire and frequent fires could lead to their degradation. The fact that some of these forest communities occur in sheltered ravines and are protected by large boulders protects them from excessive fire damage. It is, however, important that management plans are put in place to prevent accidental fires in these communities that would negatively affect the vegetation composition and structure.

The Syzygium cordatum-Ischaemum fasciculatum Woodland (11) corresponds with the Syzygium cordatum-Miscanthus 
junceus Short Thicket as described by Van Staden and Bredenkamp (2005). This community occurs in the narrow ravines along three large tributaries of the Matlabas River in the mountainous areas of Marakele as well as along the source of the Mamba-, Sterkstroom- and Matlabas rivers and is regarded as being in an excellent condition in terms of plant species composition with mostly climax species present (Online Appendix 1) and with respect to vegetation structure (Table 2).

Plant community 12 (Leptochloa fusca-Fuirena pubescens forbland) represents the higher-lying plateau wetlands and forblands group (Figure 2) and comprises seasonal waterlogged sponges (wetlands) that feed the various river/stream systems of the park. These relatively high-lying subcommunities are situated on fertile soils with the rock cover ranging from $0 \%$ to $90 \%$, with rocks occurring in the fastflowing upper sections drainage line streams and no rocks in the wetland forbland areas.

This group (wetlands and forblands) is susceptible to fire. Frequent fires in these wetland communities could lead to the degradation, drying out and compacting of the soil that would cause a serious loss of ecosystem functioning. If fire is, however, kept out completely, it could lead to bush encroachment, which would be detrimental for this group. A three-year burning cycle could be investigated for these wetland plant communities. This group has a low diversity and species richness because of them being relatively homogeneous (Figure 3).

\section{Conclusion}

The Braun-Blanquet approach proved to be an efficient way to identify, classify and map floristically defined plant communities in the field. This study resulted in the identification, classification and description of 16 different and clearly recognisable sub-communities and two variants that can be grouped into 12 main plant communities that can be ecologically interpreted. The high-lying vegetation has clear affinities with the Bankenveld and Drakensberg vegetation and can be classified as inselbergs of highaltitude vegetation. The low-lying and midslope vegetation is typical of the bushveld areas and shows clear affinities to these areas.

Overall, the plant communities of the high-altitude grassland and shrubland in the midslope areas have the highest diversity. These rocky areas provide various microhabitats to a number of different plant species. According to Brown and Bezuidenhout (2018), rocky, highlying areas also act as refuge sites for plants from adjacent areas that are affected by animal utilisation. The forests have a moderate to low diversity and species richness. This can be ascribed to the well-developed tree and shrub layer preventing the growth of large numbers of herbaceous species. The wetland and river plant communities are stable and relatively homogeneous ecosystems with low species richness compared to the other plant communities.
Sambare et al. (2011) found that the tree species diversity along riverine areas was low, similar to what was found in this study.

The mountain vegetation of the Marakele has a high species richness and diversity of species that add to the conservation value of the park. This study incorporated previous data as well as new data collected in the study area and has resulted in a more detailed and comprehensive classification of the vegetation than previous studies. This research therefore provides valuable data on the mountainous ecosystems present in Marakele.

An understanding of the plant communities and their associated habitats is of fundamental importance for compiling sound management and conservation strategies for Marakele. This vegetation survey and description provide baseline information that allows for vegetation assessments to conduct carrying capacity as well as similar surveys to be conducted in the future. The expansion of Marakele not only contributed to the floristic diversity of the park but also to faunal diversity because of the inclusion of new habitats into the park that made it suitable for the introduction of lions and larger herbivore species that historically occurred in this region.

\section{Acknowledgements}

South African National Parks, the park managers and staff of Marakele National Park are thanked for allowing and encouraging the research.

\section{Competing interests}

The authors declare that they have no financial or personal relationships that may have inappropriately influenced them in writing this article.

\section{Authors' contributions}

P.J.v.S. collected the data, did the initial analysis and drafted the manuscript. All authors contributed to further data analyses, data interpretation, further writing, review and editing of the manuscript.

\section{Funding information}

This research was financially supported by the University of South Africa (UNISA) and SANParks.

\section{Data availability}

The raw data is available from the first author, P.J.v.S.

\section{Disclaimer}

The views and opinions expressed in this article are those of the authors and do not necessarily reflect the official policy or position of any affiliated agency of the authors, and the publisher. 


\section{References}

Allan, E., Weisser, W., Weigelt, A., Roscher, C., Fisher, M. \& Hillebrand, H., 2011 'More diverse plant communities have higher functioning over time due to turnover in complementary dominant species', Proceedings of the National Academy of Sciences 108, 17034-17039. https://doi.org/10.1073/ pnas.1104015108

Behr, C.M. \& Bredenkamp, G.J., 1988, 'A phytosociological classification of the Witwatersrand National Botanical Garden', South African Journal of Botany 54 525-533. https://doi.org/10.1016/S0254-6299(16)31248-0

Bezuidenhout, H., 2009, 'The classification, mapping and description of the vegetation of the Rooipoort Nature Reserve, Northern Cape, South Africa', Koedoe 51(1), a695. https://doi.org/10.4102/koedoe.v51i1.695

Bezuidenhout, H., Biggs, H.C. \& Bredenkamp, G.J., 1996, 'A process supported by the utility BBPC for analyzing Braun Blanquet data on a personal computer', Koedoe 39, 107-112.

Bredenkamp, G.J \& Brown, L.R., 2003, 'A reappraisal of Acocks' Bankenveld: Origin and diversity of vegetation types', South African Journal of Botany 69, 7-26. https:// diversity of vegetation types', South African
doi.org/10.1016/S0254-6299(15)30357-4

Brown, L.R., Bredenkamp, G.J. \& Van Rooyen, N., 1996, 'The phytosociology of the northern section of the Borakalalo Nature Reserve, South Africa', Koedoe 39, 9-24. https://doi.org/10.4102/koedoe.v39i1.279

Brown, L.R., Du Preez P.J., Bezuidenhout, H., Bredenkamp, G.J., Mostert, T.H.C. \& Collins, N.B., 2013, 'Guideline for phytosociological classifications and description of vegetation in southern Africa', Koedoe 55, 1-10. https://doi.org/10.4102/ koedoe.v55i1.1103

Brown, L.R. \& Bezuidenhout, H., 2018, 'Ecosystem description and diversity of the Jurisdam Seekoegat Section of the Mountain Zebra National Park, South Africa', South African Journal of Botany 118, 166-178. https://doi.org/10.1016/j. sajb.2018.07.013

Coetzee, B.J., 1975, 'A phytosociological classification of the Rustenburg Nature Reserve', Bothalia 11, 561-580. https://doi.org/10.4102/abc.v11i4.1502

Edwards, D., 1983, 'A broad-scale structural classification of vegetation for practical purposes', Bothalia 14, 705-712. https://doi.org/10.4102/abc. v14i3/4.1231

Filmalter, N., 2010, 'A vegetation classification and management plan for the Hondekraal section of the Loskopdam Nature Reserve', M Tech dissertation, University of South Africa, Pretoria.

Grobbelaar, N., 2002, Cycads of Southern Africa, Four Images Bureau \& Printers, Pretoria, p. 334

Guiasu, R.C. \& Guiasu, S., 2010, 'The Rich-Gini-Simpson quadratic index of biodiversity', Natural Science 02, 1130-1137. https://doi.org/10.4236/ns.2010.210140

Hill, M.O., 1979, 'TWINSPAN - A Fortran program for arranging multivariate data in an ordered two-way table by classification of individuals and attributes', Cornell University, Ithaca, NY.

Jost, L., 2006, 'Entropy and diversity', Oikos 113, 363-376. https://doi org/10.1111/j.2006.0030-1299.14714.x

Land Type Survey Staff, 1988, 'Land types of the maps 2426 Thabazimbi, 2428 Nylstroom', Memoirs of the agricultural natural Resources of South Africa No.10, pp. 1-431, Department of Agriculture and Water Supply, Pretoria.
Mucina, L. \& Van Staden, P.J., 2003, 'Marakele Afromontane Forests', in G. Von Maltitz (ed.). Classification system for South African indigenous forests: An objective classification for the Department of Water Affairs and Forestry, Council for Scientific and Industrial Research, Environmentek report ENV-P-C 2003-017.

Mucina, L. \& Rutherford, M.C., 2006, The vegetation of South Africa, Lesotho and Swaziland, Strelitzia 19, South African National Biodiversity Institute, Pretoria.

Novellie, P. \& Kraaij, T., 2010, 'Evaluation of Themeda triandra as an indicator for monitoring the effects of grazing and fire in the Bontebok National Park', Koedoe 52, 5 pages, https://doi.org/10.4102/koedoe.v52i1.977

Partridge, T.C., Kerr, S.J., Metcalfe, S.E., Scott, L., Talma, A.S. \& Vogel, J.C., 1993, 'The Pretoria Saltpan: A 200000 year southern African lacustrine sequence' Palaeogeography Palaeoclimatology Palaeoecology 101, 317-337. https://doi. org/10.1016/0031-0182(93)90022-B

Roleček, J., Tichý, L., Zelený, D. \& Chytrý, M., 2009, 'Modified TWINSPAN 986 classification in which the hierarchy respects cluster heterogeneity', Journal of Vegetation Science 20, 596-602. https://doi.org/10.1111/j.1654-1103.2009.01062.x

Sambare, O., Bognounou, F., Wittig, R. \& Thiombiano, A., 2011, 'Woody species composition, diversity and structure of riparian forests of four watercourses types in Burkina Faso', Journal of Forestry Research 22, 145-158. https://doi. org/10.1007/s11676-011-0143-2

Scott, L., 1982, 'A late Quarternary pollen record from the Transvaal bushveld, South Africa', Quaternary Research 17, 339-370. https://doi.org/10.1016/00335894(82)90028-X

Shannon, C.E. \& Weaver, W., 1949, The mathematical theory of communication, p. 144 , University of Illinois Press, Champaign, IL.

Soil Classification Working Group, 1991, 'Soil classification: A taxonomic system for South Africa', Memoirs on the Agricultural Natural Resources of South Africa 15, $1-262$.

Tichy, L. \& Holt, J., 2006, 'JUICE program for management and classification of ecological data; program manual', Vegetation Science Group, Czech Republic, p. 98.

Van der Maarel, E., 2007, 'Transformation of cover-abundance values for appropriate numerical treatment - Alternatives to the proposals by Podani', Journal of Vegetation Science 18, 767-770. https://doi.org/10.1111/j.1654-1103.2007. tb02592.x

Van Staden, P.J., 2002, 'An ecological study of the plant communities of Marakele National Park', MSc dissertation, University of Pretoria, Pretoria.

Van Staden, P.J., 2007, A phytosociological study of the newly acquired land as well as the existing land of Marakele National Park and the contractual section, Marakele Park (Pty) Ltd in the Limpopo Province, South Africa, Unpublished report, SANParks.

Van Staden, P.J., 2015, 'Aspects of the vegetation ecology of the Marakele National Park and Marakele Park (Pty) Ltd, Limpopo Province, South Africa', PhD thesis, University of Pretoria, Pretoria.

Van Staden, P.J. \& Bredenkamp, G.J., 2005, 'Major plant communities of the Marakele National Park', Koedoe 48, 59-70. https://doi.org/10.4102/koedoe.v48i2.101

Van Staden P.J. \& Bredenkamp, G.J., 2006, 'A floristic analysis of forest and thicket vegetation of the Marakele National Park', Koedoe 49, 15-32. https://doi. org/10.4102/koedoe.v49i1.109

Van Staden, P.J., Bredenkamp, G.J., Bezuidenhout, H. \& Ferreira, S., 2016, 'The effects of elephants and fire on vegetation at Marakele National Park, South Africa', Pachyderm 58, 107-122. 